\title{
The Origin of Etch Pits Recorded on Residual Grain Surfaces from Kaolinized Granitic Rocks West Region Cameroon
}

\author{
A. S. L. Wouatong ${ }^{1}$, B. P. K. Yerima 2 , R. Yongue Fouateu ${ }^{3}$, A. Mvondo Ze ${ }^{2}$ \& G. E. Ekodeck ${ }^{3}$ \\ ${ }^{1}$ Department of Earth Sciences, Faculty of Sciences, University of Dschang, Cameroon \\ ${ }^{2}$ Department of Soil Sciences, Faculty of Agronomy and Agricultural Sciences, University of Dschang, Cameroon \\ ${ }^{3}$ Department of Earth Sciences, Faculty of Sciences, University of Yaounde I, Cameroon \\ Correspondence: A. S. L. Wouatong, Department of Earth Sciences, Faculty of Sciences, University of Dschang, \\ PO Box 67 Dschang, Cameroon. Tel: 237-96-31-5247. E-mail: aslwouat@yahoo.com
}

Received: December 14, 2012 Accepted: January 28, 2013 Online Published: March 18, 2013

doi:10.5539/esr.v2n2p93 URL: http://dx.doi.org/10.5539/esr.v2n2p93

\begin{abstract}
The weathering of some granitic rocks in the West Region of Cameroon (Central Africa) was examined by X-ray diffraction (XRD) and X-ray fluorescence Spectrometer (XRF) in conjunction with Scanning Electron Microscopy (SEM). Kaolinite and illite were the most predominant weathering products whereas gibbsite, goethite and maghemite were also found in small amounts; only residual quantities of quartz and potassium feldspar were observed. The geochemical study shows the mobility of major elements during the progressive kaolinization of granitic rocks. The main trend is the loss of elements, with high losses of $\mathrm{CaO}, \mathrm{Na}_{2} \mathrm{O}$ and $\mathrm{MgO}$, slight losses of $\mathrm{SiO}_{2}$ while $\mathrm{Al}_{2} \mathrm{O}_{3}$ and $\mathrm{K}_{2} \mathrm{O}$ appear to increase with weathering intensity. Chemical index of alteration (CIA) shows a high value (68-95\%). The scanning electron microscope analysis reveals the existence of several surface features that reflect the effect of mainly chemical actions on the quartz and K-feldspar grains. Quartz and K-feldspar crystals from kaolinized granitic rocks show low to very high chemical etching attributed to weathering under moderate to severe environmental conditions such as low $\mathrm{pH}$, high temperature and humidity and extreme leaching typical of tropical climatic conditions. Etched pit densities on quartz surfaces increase with weathering, as a result of increasing silica concentrations in pore fluids.
\end{abstract}

Keywords: weathering, kaolinization, SEM, dissolution, chemical etching, etch pit

\section{Introduction}

A tremendous amount of literature exits on the mechanism of chemical weathering under different geomorphic and paleoclimatic conditions, provided by many investigators (Stanley, 1968; Lelong, 1969; Pedro, 1964, 1968; Millot, 1971; Krinsley \& Cavallero, 1970; Berner \& Holdren, 1979; Nahon et al., 1979, 1982; Tardy, 1993; Kitagawa et al., 1994; Wilson, 1995; Wouatong et al., 1996; Wouatong et al., 2005; Deepthy \& Balakrishnan, 2005; Nguetnkam et al., 2008; Ndjigui et al., 2008; Kamgang et al., 2009). The main chemical factors that usually control the weathering of rocks include: solution $\mathrm{pH}$, parent material composition and crystallinity, microenvironment, oxidation-reduction potentials, temperature and ionic strength. Geochemists interested in weathering and alteration processes have long recognized the need for a better understanding of the nature of the mineral surface and its influence on dissolution reactions. Lasaga (1981) and Berner et al. (1980) have previously pointed out the importance of active sites concentration in silicate dissolution kinetics. Indeed, etch pits have been identified in many naturally dissolved samples (Berner \& Schott, 1982; Berner \& Holdren, 1979) and used as evidence for interface-controlled dissolution. These poorly characterized "active sites" consist of dislocation edges, micro fractures, point defects, kinks, and grain or twin boundaries (Helgeson et al., 1984).

The actual process by which dislocations nucleate etch pits at the mineral surface has not been extensively investigated. The application of the theories for etch pit formation have been developed as a tool in interpretation of the nature of fluids interaction with mineral surfaces, as pointed out by Lasaga (1983) and Lasaga and Blum (1986). According to these workers, crystal growth involves the transport of dissolved species to and from the surface of a crystal and various chemical reactions occurring at the surface. The latter include adsorption, ion exchange, and dehydration of ions, formation of two-dimensional nuclei on the surface, diffusion along the surface and ion pair formation among others. The rate of growth is limited by the slowest step within a whole chain of 
processes and the nature of the rate-limiting step is relatively unknown. However, as a first approximation, the rate of crystal growth can be characterized as being controlled either by transport of ions to the surface (transport-controlled), by reactions at the surface (surface-reaction controlled), or by a combination of both processes. Transport-controlled processes can induce surface-reaction controlled processes observed on quartz and K-feldspar growth.

According to Berner (1981), actual mechanisms to explain surface-reaction controlled growth are varied. The two most commonly cited ones are surface nucleation and dislocation control. Quartz in particular exhibits slow dissolution although some first order information regarding this dissolution on the overgrowth surface of quartz has not been adequately documented. A paucity of information exists on the weathering and transformation of primary minerals to secondary minerals in this region. Information on the type of secondary minerals in this region is important to their use. A good understanding of the weathering processes and the resulting minerals will enhance prospection of these earth materials for application in various domains (pottery, ceramic, refractory, etc.). In this study, the crystal surfaces of quartz and K-feldspar collected from kaolinized granitic rocks in the West Region of Cameroon (Figure 1) were investigated using XRD, chemical composition and SEM, in order to obtain information about the origin of the surface features and their evolution during kaolinization.

\section{Materials and Methods}

\subsection{Geology of the Region}

The area under study belongs to the western part of Cameroon commonly called Western Highlands with altitudes varying from $1300 \mathrm{~m}$ to $2700 \mathrm{~m}$ (Figure 1). Its topography is characterized by pyramidal stages with different vegetation types, which are typical of the grassland region of West Cameroon. This distinctive vegetation is of herbaceous savannah with thorn shrub which appears to be related to the human activities. The climate of these highlands is similar to the Sudanese tropical type but modified by altitude. It is characterized by two contrasting seasons i.e, a dry season of four months, from November to March with an average temperature of $25-30^{\circ} \mathrm{C}$ and a rainy season of eight months, with a higher amount of rainfall in August, September and October. The estimated annual precipitation in the study area varies from 1500 to $2500 \mathrm{~mm}$ per year.

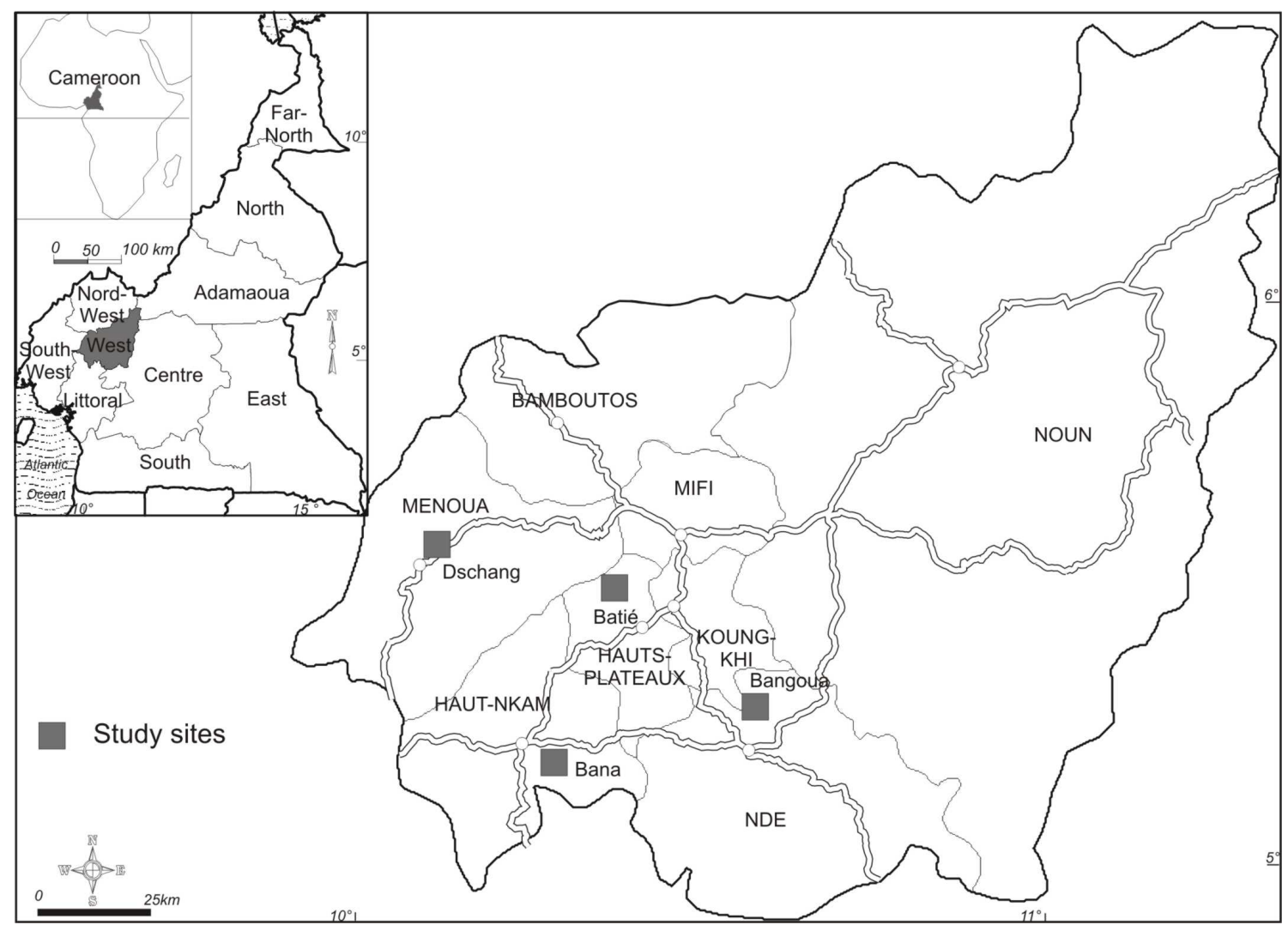

Figure 1. The sampling sites in the west region of Cameroon 
This region belongs to the central part of the Cameroon Line $\left(\mathrm{N} 30^{\circ} \mathrm{E}\right)$ marked by about 60 alkaline anorogenic complexes e.g Koupé, Bana and Ntumbey with various types of rocks (metamorphic, plutonic and volcanic) and representing a chain of Tertiary to Recent volcanoes stretching along the Cameroon Line. According to Ngako et al. (1991), Marzoli et al. (2000), Tagne-Kamga (2003), and Njanko et al. (2006), this region belongs to the Central Cameroon Shear Zone characterized by a main shear zone with their secondary branches associated with abundant granitoids of Pan African age, i.e, 630-550 Ma, for example Batié, Fomepia and Tibati. The basement rocks of the region are composed of gneissose rocks such as orthogneiss, porphyroid granite and migmatite. The main rock is granite (Batié granite, Dschang granite, and Bangoua granite) and veins of pegmatite, quartzite and aplites with occasionally some basic rocks (monzonite, granodiorite, monzodiorite) such as xenoliths (Figure 2). These coarse-grained granites are leucocratic and outcrop as boulders. The constituent minerals of these granites are quartz (25-40\%) and K-feldspar (15-38\%) composed of microcline and orthoclase. Some crystals show biotite, plagioclase and iron oxides as inclusion and sericite as weathered products. Biotite (less than 10\%) occurs as flakes and are rich in iron with zirconium present as inclusions. Chloritization is commonly observed in Batié granite. Plagioclase (22-30\%) occurs in form of oligoclase. Amphibole (less than 1\%) is a green hornblende observed in Batié and Dschang granites. Sphene, allanite, apatite, zirconium and magnetite are observed as accessory minerals. Geochemical analysis of these granites show 70-75\% $\mathrm{SiO}_{2}, 11-15 \% \mathrm{Al}_{2} \mathrm{O}_{3}, 2-3 \% \mathrm{Fe}_{2} \mathrm{O}_{3}, 00-1.5 \% \mathrm{MnO}$ and $\mathrm{MgO}$ and 3.5-5.5\% $\mathrm{Na}_{2} \mathrm{O}$ and $\mathrm{K}_{2} \mathrm{O}$ (Nana, 1988; Talla, 1995; Kuepouo, 2004; Kwekam, 2005). These granites are intensively weathered and are quarried by the indigenous population for sand. Mica and kaolin minerals occur as secondary products of amphiboles, biotites and feldspars. The weathered mantle is very thick, varying from $20 \mathrm{~m}$ to more than $100 \mathrm{~m}$ deep.

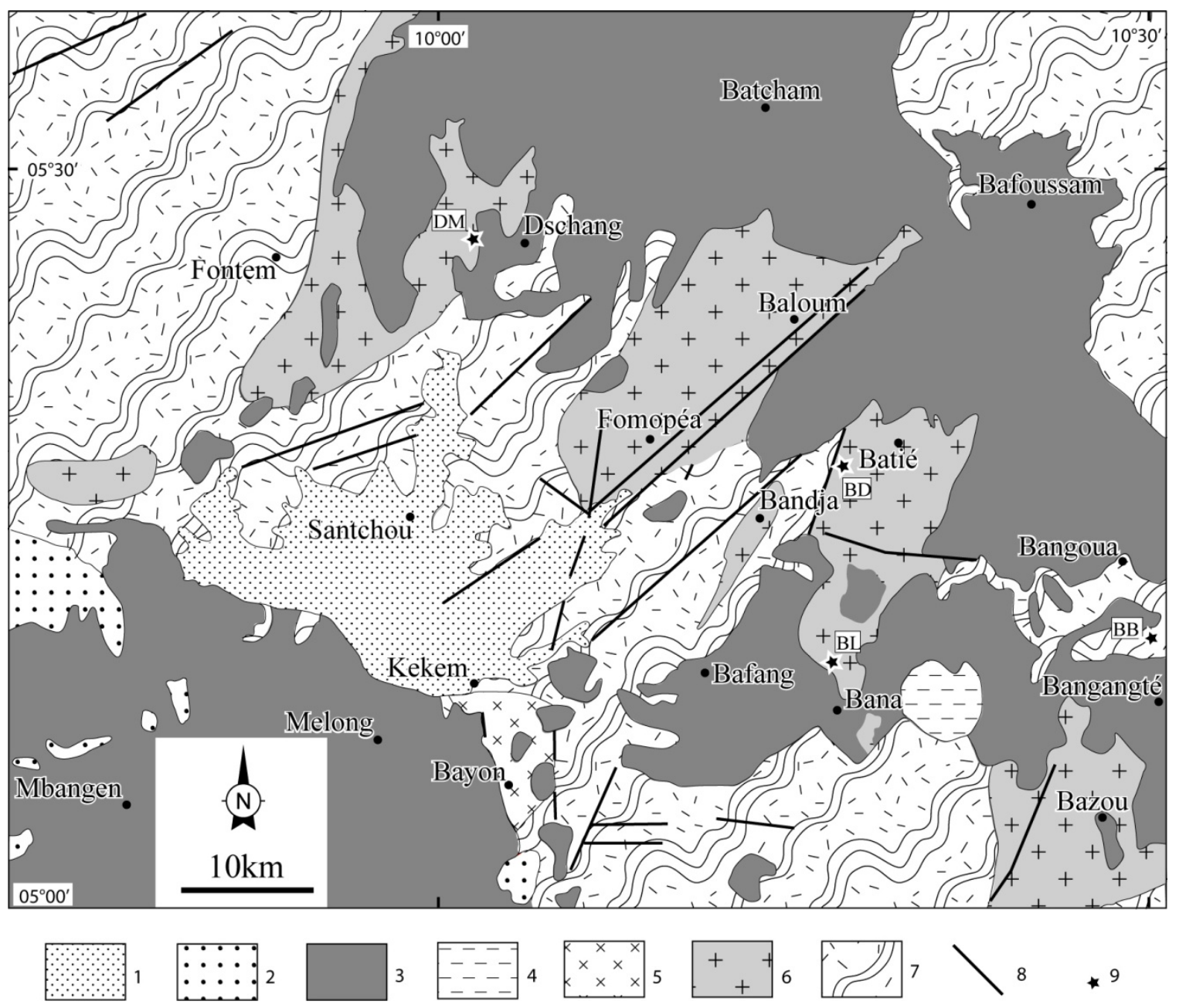

Figure 2. The sampling localitions and sampling points on the geological map of the west region: 1) quaternary alluvium; 2) cretaceous sandstone; 3 ) tertiary volcanic rocks; 4) tertiary anorogenic complex; 5) norite of Kékem; 6) panafricain granitoid; 7) undifferentiated gneiss; 8) fault; 9) sampling point 


\subsection{Sampling Area}

Twenty seven samples were collected on weathered granite (sand quarry) from different localities of the Western highlands of Cameroon around the following sites: Dschang, Batié, Bangoua and Bana (Figure 2).

In each profile (Figure 3), sampling was done at the middle flank of the interfluve from up (below the A horizons) extending down to the parent rock $(0.5-2 \mathrm{~m})$ at 1 to $5 \mathrm{~m}$ intervals depending on the thickness of the profile as follows (Table 1):

- Dschang (Menouet) (DM): 8 samples, (1317m altitude, 1001'33'’E, 5²7'27’'N) in Menoua division, (Figure 3a);

- Batié (Djedem) (BD): 7 samples, (1482m altitude, 10¹7'9'’E, $\left.5^{\circ} 18^{\prime} 22^{\prime \prime} \mathrm{N}\right)$ in Hauts plateaux division, (Figure 3b);

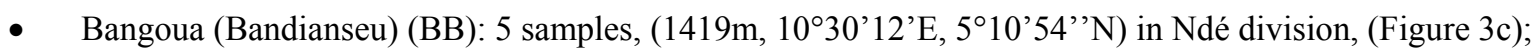

- Bana (Lembo) (BL): 7 samples, (1662m, 10¹8'81'’E, $5^{\circ} 09^{\prime} 91^{\prime \prime} \mathrm{N}$ ) in Haut Nkam division, (Figure 3d).

The analyses were performed at the Science of Earth and Planetary Materials Laboratory of the Department of Earth and Planetary System Science, Faculty of Science, in Hiroshima University, Japan.
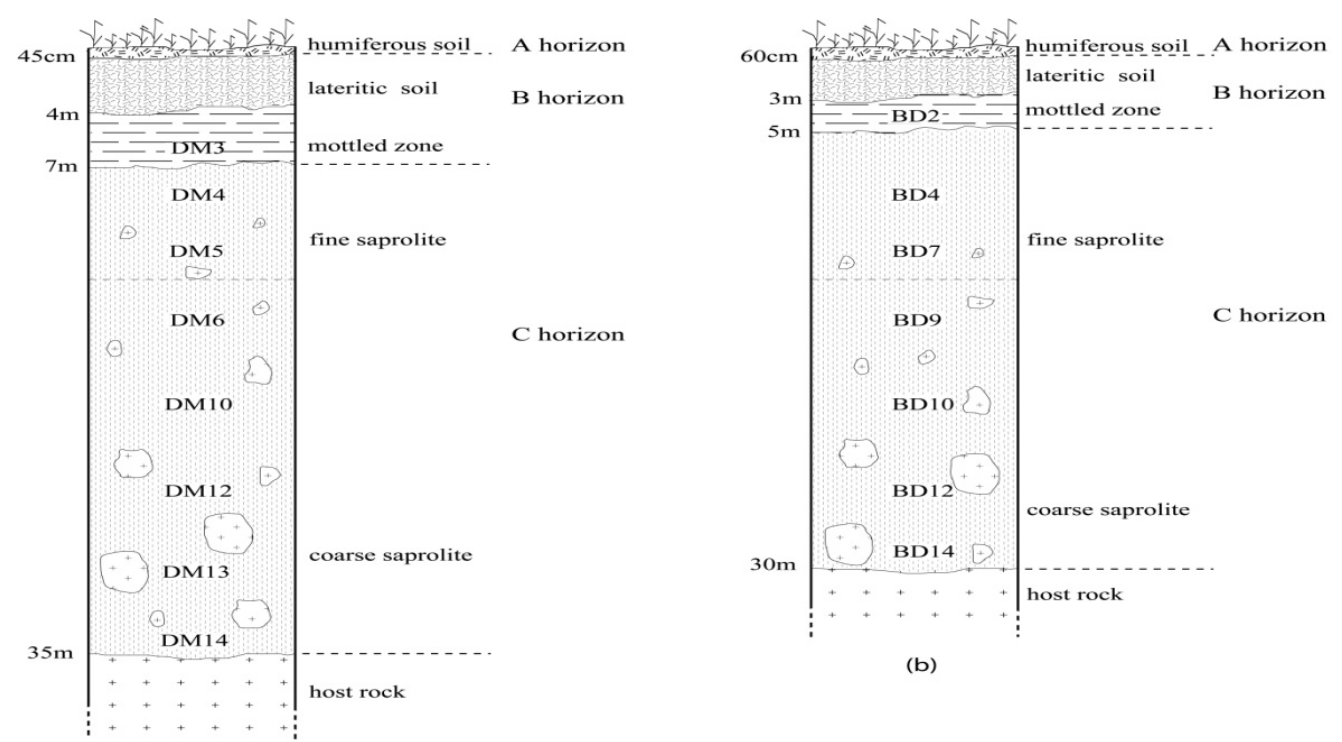

(b)

(a)
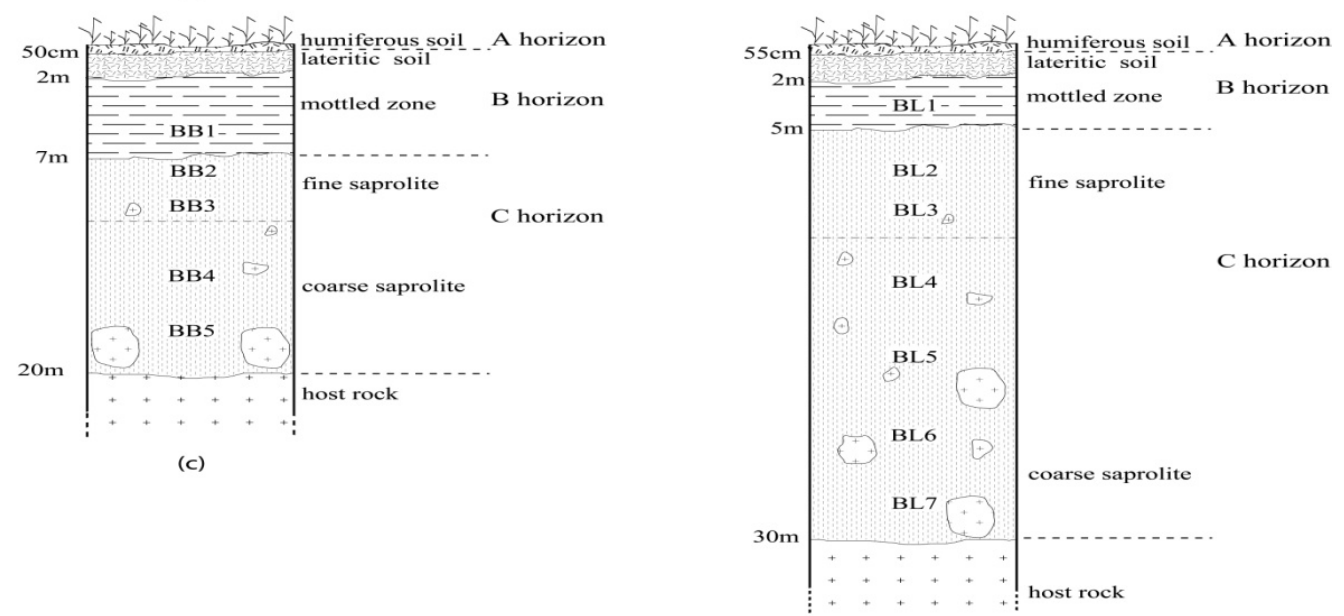

(d)

Figure 3. Presentation of representative profiles of the different sampling sites: a) Dschang, b) Batié, c) Bangoua and d) Bana 


\subsection{X-ray Diffraction}

Identification of the constituent minerals in the bulk and selected samples $(\varnothing<200 \mu \mathrm{m})$ (Table 1) and selected clay fractions $(\varnothing<2 \mu \mathrm{m})$ were determined by X-ray diffraction (XRD) methods, using a Ni-filtered Cuk $\alpha$ radiation. The samples were treated by wet sieving and sedimentation. The analytical conditions were $\mathrm{X}$-ray generator, $18 \mathrm{KW}$, 40.0 KV, $100.0 \mathrm{~mA}$, sample width, $0.02 \mathrm{deg}$, scanning speed 8.00 degrees $/ \mathrm{min}$.

Table 1. Location of sampling sites and sampling depths within given profiles at each site

\begin{tabular}{|c|c|c|}
\hline LOCALITY & SAMPLE & DEPTH $(\mathrm{m})$ \\
\hline DSCHANG (DM) & DM3 & 6 \\
\hline $1317 \mathrm{~m}$ altitude & DM4 & 8 \\
\hline $10^{\circ} 01{ }^{\prime} 33^{\prime \prime} \mathrm{E}$ & DM5 & 9 \\
\hline \multirow[t]{5}{*}{$5^{\circ} 27^{\prime} 27^{\prime} \mathrm{N}$} & DM6 & 14 \\
\hline & DM10 & 19 \\
\hline & DM12 & 24 \\
\hline & DM13 & 29 \\
\hline & DM14 & 34 \\
\hline BATIE (BD) & $\mathrm{BD} 2$ & 4 \\
\hline $1482 \mathrm{~m}$ altitude & BD6 & 7 \\
\hline $10^{\circ} 17^{\prime} 09^{\prime \prime} \mathrm{E}$ & BD7 & 9 \\
\hline \multirow[t]{4}{*}{$5^{\circ} 18^{\prime} 22^{\prime \prime} \mathrm{N}$} & BD9 & 14 \\
\hline & BD10 & 19 \\
\hline & BD12 & 24 \\
\hline & $\mathrm{BD} 14$ & 29 \\
\hline BANGOUA (BB) & BB1 & 6 \\
\hline $1419 \mathrm{~m}$ altitude & BB2 & 8 \\
\hline $10^{\circ} 30^{\prime} 12^{\prime \prime} \mathrm{E}$ & BB3 & 9 \\
\hline \multirow[t]{2}{*}{$5^{\circ} 10^{\prime} 54^{\prime \prime} \mathrm{N}$} & BB4 & 14 \\
\hline & BB5 & 19 \\
\hline BANA (BL) & BL1 & 4 \\
\hline $1665 \mathrm{~m}$ altitude & BL2 & 6 \\
\hline $10^{\circ} 18^{\prime} 81^{\prime \prime} \mathrm{E}$ & BL3 & 7 \\
\hline \multirow[t]{4}{*}{$5^{\circ} 09^{\prime} 91^{\prime} ’ \mathrm{~N}$} & BL4 & 12 \\
\hline & BL5 & 17 \\
\hline & BL6 & 22 \\
\hline & BL7 & 27 \\
\hline
\end{tabular}

\subsection{X-ray Fluorescence Spectrometer}

The parent rock, granite (RDM, RBD, RBB, and RBL) and selected saprolitic material (DM, BD, BB and BL) collected from the weathered mantle of each locality were analysed to obtain the bulk chemical composition. These analyses were carried out by X-ray fluorescence spectrometer using a Rigaku model 3030 equipped with a dual anode X-ray tube, to obtain the bulk chemical composition. The major elements were obtained using the rock standard of the Geological Survey of Japan as a control.

The samples were fused with $6 \mathrm{~g}$ of $4: 1$ mixture of lithium metaborate and lithium tetrabonate, for $20 \mathrm{~min}$ at $1100^{\circ} \mathrm{C}$, with intermittent swirling to ensure thorough mixing. The results of the analyses were calculated and expressed in the form of oxides. Detailed chemical composition of weathered rock is indispensable to determine the constituent clay minerals, leaching conditions and the degree of weathering. 


\subsection{Scanning Electron Microscope}

After XRD examination, further investigations were carried out on saprolitic materials of each profile depending on the thickness of the saprolite. The samples examined were collected from the upper part of the saprolitic zone. From the saprolitic speciments, quartz and K-feldspar grains were selected (DM5, BD7, BB3 and BL3, Figure 3) using a binocular microscope and washed with distilled water using an ultrasonic generator and then glued to aluminium specimen stubs (one stub per sample) and coated in a vacuum evaporator. Because of the high vacuum conditions in the scanning electron microscope (SEM) all samples were dehydrated before viewing. The air drying (AD) method of Reynolds and Gorsline (1991) which is widely employed for observation of aggregated texture was used. The grains were viewed with a Nova Scan 30 Akashi-alpha 10 SEM. Each grain was studied in detail from low to high magnification and the micro textures and micro surface features of the grains were observed and photographed.

\section{Results}

\subsection{Description of Profiles}

The profiles (Figures 3: a, b, c and d) are very thick, deep, well differentiated, and well developed comprising from the top to the bottom of:

- An organic matter-rich A horizon, less than $50 \mathrm{~cm}$ thick, with a dark brown (7.5 YR 3/2) colour, a sandy loam texture and crumb structure.

- A thick B horizon made up of a lateritic surface and mottled subsurface composed of a 200-300 cm thick, reddish brown (5YR 5/4), reddish yellow (7.5 YR 6/8) and pale brown (10 YR 6/3), clayey sand, gravels and abundant quartz grains. The transition to the saprolite below is gradual.

- A weathered $\mathbf{C}$ horizon (an upper saprolitic zone and a lower saprock zone) (Nahon, 1991; Deepthy and Balakrishnan, 2005), with very thick (300-1500 cm), pale brown to very pale brown (10 YR 8/3), whitish, and yellowish colors with many slighty weathered fragments of granite, and moderately plastic mixed clayey and sandy materials. The weathered granite shows well-preserved structures and shapes of the primary minerals relative to the original rock, with few changes throughout the profile. The original structure of the granite was lost only in the upper most part of the profile due to weathering.

- The parent rock granites are both coarse and fine grained, and are greyish in colour. They are composed mainly of quartz, K-feldspar, plagioclase, and amphiboles and variable amounts of biotite; biotite and muscovite exist only in the Bangoua granite. The Bangoua granite has features of an orthogneiss. Secondary and accessory minerals are sphene, epidote, zirconium, apatite, chlorite, sericite and sesquioxides. Some of the granites (Batié and Dschang) are porphyritic due to the abundance of white K-feldspar megacrysts observed in the thin section with preferred orientation. In addition, fractures with preferred orientations were recognized at many localities suggesting that the fracture patterns were formed under the regional stress field. Many clay veins are also recognized in the granites as well as in the saprolitic zone.

\subsection{Mineralogical Composition}

The representative XRD patterns of the bulk samples collected from weathered granites from the different localities i.e, Dschang, Batié, Bangoua and Bana are presented in Figures 4a, b, c and d. 

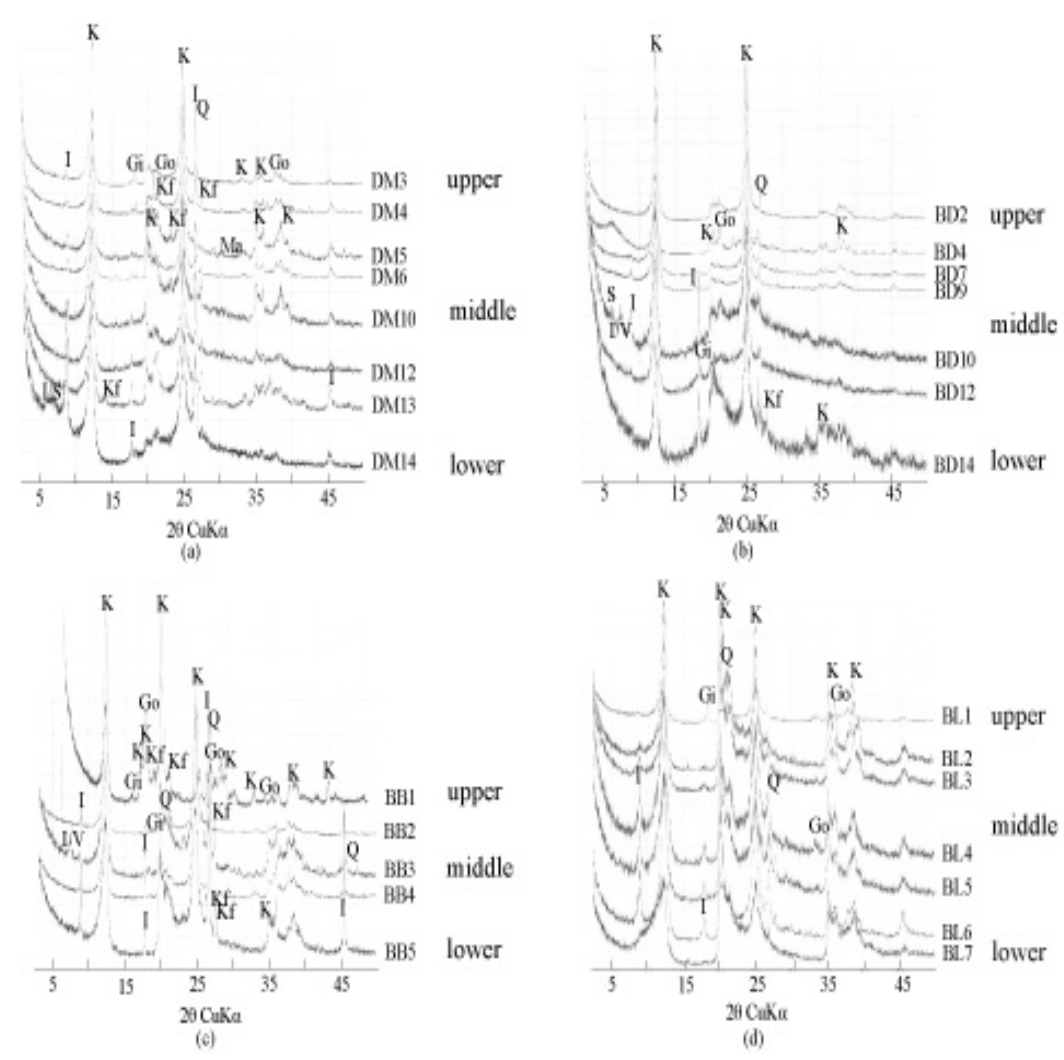

Figure 4. XRD patterns of constituent minerals of weathered granites collected from: a) Dschang, b) Batié, c) Bangoua and d) Bana. I/V: illite/vermiculite, S: smectite, I: illite, I/S: illite/smectite, K: kaolonite, Gi: gibbsite, Go: goethite, Ma: maghemite, Hm: hematite, Q: quartz, Kf: potassium feldspar, and An: anatase

After XRD analysis of bulk samples, the major constituent minerals in all the samples studied were identified following the methods of Brindley and Brown (1980) and Duane et al. (1989).

The mineralogical composition (Table 2) were identified by the following corresponding XRD peaks: kaolinite

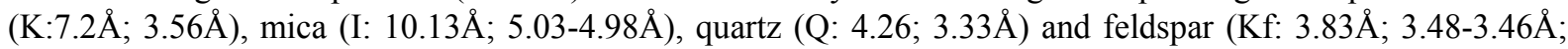

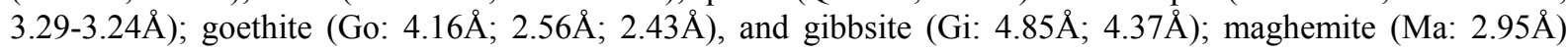
occurs within the middle part of the Dschang and Batie profiles and within the upper part of the Bangoua profile.

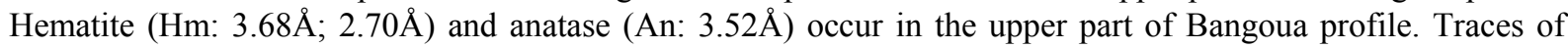
anatase occur throughout the Dschang profile and within the middle part of the Bana profile.

The mineralogical composition of the clay fraction $(\varnothing<2 \mu \mathrm{m})$ of weathered granites also show that kaolinite $(\mathrm{K})$ and illite (I) are both present in all samples of the different localities. In all profiles gibbsite appears mostly in the upper part but was observed in the lower part of the Batié profile. A trace of Illite/Smectite (I/S) was observed in the lower and middle part of the Dschang, Batié and Bangoua profiles. Goethite occurs throughout the Dschang and Batié profiles (Figures $4 \mathrm{a}$ and $4 \mathrm{~b}$ ), but was only observed at the top of Bangoua (Figure $4 \mathrm{c}$ ) and the middle to the top of the Bana profiles (Figure 4d). Hematite is observed also at the top of the Bangoua profile. Anatase is observed only at the surface of the Bangoua profile (Figure 4c), but occurs throughout the Dschang profile. All the profiles studied show numerous to trace amounts of K-feldspar throughout their profiles. XRD patterns (Figures 4a, $4 \mathrm{~b}, 4 \mathrm{c}$ and $4 \mathrm{~d}$ ) indicate the presence of quartz in all profiles studied. The semi quantitative analysis of mineral assemblage given in Table 2 shows that, kaolinite is the dominant mineral in all profiles. 
Table 2. The mineral composition assemblages and semi quantitative determination of the mineralogy of the weathered granites within the horizons of the representative profiles of each study site

\begin{tabular}{|c|c|c|c|c|c|c|c|c|c|c|c|c|c|}
\hline & & $\mathbf{I} / \mathbf{V}$ & $\mathbf{S}$ & $\mathbf{I} / \mathbf{S}$ & I & $\mathbf{K}$ & Gi & Go & Ma & $\mathbf{H m}$ & $\mathbf{Q}$ & Kf & An \\
\hline \multicolumn{14}{|c|}{ DSCHANG } \\
\hline DM3 & $6 \mathrm{~m}$ & & & & $\circ$ & $\bullet \bullet \bullet$ & $\bullet$ & o & & & $\bullet$ & & $\square$ \\
\hline DM4 & $8 \mathrm{~m}$ & & & & $\circ$ & $\bullet \bullet \bullet$ & $\bullet$ & $\bullet$ & & & $\bullet$ & ० & ० \\
\hline DM5 & $9 \mathrm{~m}$ & & & & $\bullet$ & $\bullet \bullet$ & $\bullet$ & $\circ$ & ० & & $\bullet$ & o & ○ \\
\hline DM6 & $14 \mathrm{~m}$ & & & & $\bullet$ & $\bullet \bullet$ & $\bullet$ & $\square$ & & & $\bullet$ & o & ○ \\
\hline DM10 & $19 \mathrm{~m}$ & & $\square$ & $\square$ & $\bullet$ & $\bullet \bullet$ & $\bullet$ & $\square$ & & & $\bullet$ & o & ○ \\
\hline DM12 & $24 \mathrm{~m}$ & & & $\square$ & $\bullet \bullet$ & $\bullet \bullet$ & $\circ$ & $\bullet$ & & & $\bullet$ & ० & ० \\
\hline DM13 & $29 \mathrm{~m}$ & & & $\square$ & $\bullet \bullet$ & $\bullet \bullet$ & $\circ$ & $\bullet$ & & & $\bullet$ & o & O \\
\hline DM14 & $34 \mathrm{~m}$ & & & $\bullet$ & $\bullet \bullet$ & $\bullet \bullet$ & $\square$ & $\bullet$ & & & $\bullet$ & $\square$ & ○ \\
\hline \multicolumn{14}{|c|}{ BATIE } \\
\hline $\mathrm{BD} 2$ & $4 \mathrm{~m}$ & & & & $\square$ & $\bullet \bullet \bullet$ & & $\square$ & & & $\bullet$ & & \\
\hline BD4 & $7 \mathrm{~m}$ & & & ० & $\circ$ & $\bullet \bullet \bullet$ & $\square$ & $\square$ & $\square$ & & $\bullet$ & $\square$ & \\
\hline BD7 & $9 \mathrm{~m}$ & & & & $\circ$ & $\bullet \bullet \bullet$ & $\circ$ & o & $\square$ & & $\bullet$ & $\square$ & \\
\hline BD9 & $14 \mathrm{~m}$ & & & & $\bullet$ & $\bullet \bullet \bullet$ & $\circ$ & & $\square$ & & $\bullet$ & $\square$ & \\
\hline BD10 & $19 \mathrm{~m}$ & ○ & ० & & $\bullet$ & $\bullet \bullet \bullet$ & $\bullet \bullet$ & ○ & $\square$ & & $\bullet$ & ○ & \\
\hline BD12 & $24 \mathrm{~m}$ & $\square$ & $\square$ & & $\bullet$ & $\bullet \bullet \bullet$ & $\bullet \bullet$ & ० & & & $\bullet$ & ० & \\
\hline BD14 & $29 \mathrm{~m}$ & & & & ○ & $\bullet \bullet \bullet$ & $\bullet \bullet$ & ० & & & $\bullet$ & ० & \\
\hline \multicolumn{14}{|c|}{ BANGOUA } \\
\hline BB1 & $6 \mathrm{~m}$ & & & & $\square$ & $\bullet \bullet \bullet$ & $\circ$ & $\bullet \bullet$ & $\bullet$ & ○ & $\bullet$ & o & $\bullet$ \\
\hline BB2 & $8 \mathrm{~m}$ & & & & $\circ$ & $\bullet \bullet \bullet$ & $\circ$ & ○ & $\square$ & ○ & $\bullet$ & ○ & ○ \\
\hline BB3 & $9 \mathrm{~m}$ & ० & & & $\bullet$ & $\bullet \bullet \bullet$ & $\circ$ & ० & $\square$ & & $\bullet$ & ० & \\
\hline BB4 & $14 \mathrm{~m}$ & & & & $\bullet$ & $\bullet \bullet \bullet$ & $\circ$ & ० & & & $\bullet$ & ० & \\
\hline BB5 & $19 \mathrm{~m}$ & & & & $\bullet$ & $\bullet \bullet \bullet$ & $\square$ & $\square$ & & & $\bullet$ & • & \\
\hline \multicolumn{14}{|l|}{ BANA } \\
\hline BL1 & $4 \mathrm{~m}$ & & & & $\square$ & $\bullet \bullet$ & $\bullet$ & $\square$ & & & $\bullet$ & $\square$ & \\
\hline BL2 & $6 \mathrm{~m}$ & & & & $\circ$ & $\bullet \bullet$ & $\bullet$ & $\square$ & & & $\bullet$ & o & \\
\hline BL3 & $7 \mathrm{~m}$ & & & & $\circ$ & $\bullet \bullet$ & $\bullet$ & o & & & $\bullet$ & o & \\
\hline BL4 & $12 \mathrm{~m}$ & & & & $\bullet$ & $\bullet \bullet$ & $\bullet$ & 0 & & & $\bullet$ & o & $\square$ \\
\hline BL5 & $17 \mathrm{~m}$ & & & & $\bullet$ & $\bullet \bullet$ & $\circ$ & o & & & $\bullet$ & o & \\
\hline BL6 & $22 \mathrm{~m}$ & & & & $\bullet$ & $\bullet \bullet \bullet$ & $\circ$ & $\square$ & & & $\bullet$ & o & \\
\hline BL7 & $27 \mathrm{~m}$ & & & & $\square$ & $\bullet \bullet$ & $\circ$ & & & & ○ & ० & \\
\hline
\end{tabular}

\subsection{Geochemical Composition}

The chemical composition of different saprolites shows a wide variation in $\mathrm{Si}, \mathrm{Ti}, \mathrm{Al}, \mathrm{Fe}, \mathrm{Mn}, \mathrm{Mg}, \mathrm{Ca}, \mathrm{Na}$ and $\mathrm{K}$ contents (Table 3). 
Table 3. Chemical composition of the weathered granite and parent rock of the various samples of the profiles of each study site

\begin{tabular}{|c|c|c|c|c|c|c|c|c|c|c|c|c|}
\hline & $\mathrm{SiO}_{2}$ & $\mathrm{TiO}_{2}$ & $\mathrm{Al}_{2} \mathrm{O}_{3}$ & $\mathrm{Fe}_{2} \mathrm{O}_{3}$ & $\mathrm{MnO}$ & $\mathrm{MgO}$ & $\mathrm{CaO}$ & $\mathrm{Na}_{2} \mathrm{O}$ & $\mathrm{K}_{2} \mathrm{O}$ & $\mathrm{P}_{2} \mathrm{O}_{5}$ & LOI & Total \\
\hline \multicolumn{13}{|c|}{ DSCHANG } \\
\hline DM3 & 45.65 & 1.81 & 32.83 & 3.32 & 0.11 & 0.07 & 0.04 & 0.00 & 0.08 & 0.03 & 13.55 & 97.49 \\
\hline DM4 & 46.26 & 1.11 & 28.15 & 6.81 & 0.62 & 0.21 & 0.21 & 0.04 & 0.28 & 0.18 & 12.62 & 96.24 \\
\hline DM5 & 46.75 & 1.25 & 24.44 & 2.45 & 0.02 & 0.68 & 0.71 & 0.42 & 2.05 & 0.08 & 19.33 & 98.18 \\
\hline DM6 & 46.23 & 1.28 & 30.19 & 4.89 & 0.02 & 1.13 & 0.19 & 0.05 & 1.85 & 0.07 & 12.57 & 98.47 \\
\hline DM10 & 49.83 & 1.42 & 27.11 & 2.78 & 0.02 & 0.64 & 0.52 & 0.47 & 2.43 & 0.06 & 13.38 & 97.66 \\
\hline DM12 & 40.36 & 1.29 & 28.51 & 10.86 & 0.04 & 1.02 & 0.04 & 0.03 & 2.58 & 0.22 & 12.55 & 97.50 \\
\hline DM13 & 39.10 & 1.64 & 29.89 & 10.25 & 0.05 & 0.41 & 0.14 & 0.03 & 1.07 & 0.09 & 15.44 & 98.11 \\
\hline DM14 & 38.43 & 2.13 & 21.22 & 7.62 & 0.04 & 0.65 & 0.81 & 0.18 & 0.64 & 0.04 & 25.14 & 96.9 \\
\hline$R D M$ & 69.24 & 0.47 & 15.30 & 3.36 & 0.04 & 0.57 & 1.77 & 3.56 & 5.49 & 0.19 & & 96.63 \\
\hline \multicolumn{13}{|l|}{ BATIE } \\
\hline BD2 & 68.18 & 0.51 & 19.5 & 3.10 & 0.02 & 0.16 & 0.01 & 0.01 & 0.70 & 0.04 & 7.68 & 99.91 \\
\hline BD4 & 70.21 & 0.38 & 18.01 & 2.20 & 0.02 & 0.10 & 0.01 & 0.01 & 1.02 & 0.03 & 6.53 & 98.52 \\
\hline BD7 & 69.18 & 0.41 & 17.6 & 2.25 & 0.02 & 0.14 & 0.03 & 0.12 & 3.90 & 0.05 & 5.22 & 99.17 \\
\hline BD9 & 66.50 & 0.07 & 20.03 & 1.10 & 0.00 & 0.03 & 0.02 & 0.30 & 7.66 & 0.02 & 3.75 & 99.48 \\
\hline BD10 & 68.70 & 0.42 & 16.08 & 2.40 & 0.01 & 0.38 & 0.03 & 0.20 & 6.75 & 0.05 & 4.35 & 99.37 \\
\hline BD12 & 69.90 & 0.40 & 16.71 & 2.78 & 0.03 & 0.29 & 0.02 & 0.14 & 6.20 & 0.04 & 4.77 & 100.7 \\
\hline BD14 & 66.08 & 0.60 & 16.28 & 4.90 & 0.03 & 0.32 & 0.05 & 0.14 & 5.91 & 0.18 & 4.83 & 99.32 \\
\hline$R B D$ & 71.93 & 0.37 & 14.22 & 2.89 & 0.05 & 0.33 & 1.25 & 3.81 & 4.33 & 0.12 & & 99.27 \\
\hline \multicolumn{13}{|c|}{ BANGOUA } \\
\hline BB1 & 32.67 & 7.59 & 27.41 & 20.27 & 0.06 & 0.18 & 0.02 & 0.00 & 0.31 & 0.26 & 11.67 & 100.9 \\
\hline BB2 & 57.6 & 1.19 & 23.91 & 5.25 & 0.02 & 0.17 & 0.02 & 0.00 & 3.27 & 0.12 & 8.09 & 99.74 \\
\hline BB3 & 66.57 & 0.30 & 19.05 & 2.00 & 0.03 & 0.34 & 0.01 & 0.08 & 0.65 & 0.05 & 8.43 & 97.51 \\
\hline BB4 & 65.37 & 0.27 & 21.10 & 2.09 & 0.12 & 0.17 & 0.01 & 0.00 & 4.89 & 0.06 & 5.77 & 99.85 \\
\hline BB5 & 69.43 & 0.19 & 16.71 & 1.52 & 0.01 & 0.24 & 0.01 & 0.15 & 2.30 & 0.02 & 6.61 & 97.19 \\
\hline$R B B$ & 71.25 & 1.18 & 13.45 & 2.86 & 0.07 & 0.20 & 0.72 & 3.94 & 5.13 & 0.01 & & 98.86 \\
\hline \multicolumn{13}{|l|}{ BANA } \\
\hline BL1 & 58.6 & 0.01 & 28.18 & 1.70 & 0.02 & 0.00 & 0.39 & 0.19 & 1.42 & 0.02 & 9.45 & 99.98 \\
\hline BL2 & 59.00 & 0.02 & 29.70 & 0.90 & 0.03 & 0.00 & 0.36 & 0.10 & 2.50 & 0.10 & 7.11 & 99.82 \\
\hline BL3 & 58.00 & 0.60 & 26.10 & 3.40 & 0.04 & 0.00 & 0.36 & 0.20 & 5.70 & 0.04 & 5.25 & 99.69 \\
\hline BL4 & 51.50 & 1.10 & 29.10 & 5.80 & 0.05 & 0.40 & 0.35 & 0.05 & 3.20 & 0.10 & 6.91 & 98.16 \\
\hline BL5 & 58.10 & 0.70 & 26.20 & 4.60 & 0.04 & 0.90 & 0.38 & 0.20 & 5.30 & 0.10 & 3.15 & 99.67 \\
\hline BL6 & 64.10 & 0.10 & 23.60 & 0.60 & 0.01 & 0.00 & 0.36 & 0.30 & 6.40 & 0.01 & 4.31 & 99.79 \\
\hline BL7 & 57.80 & 0.03 & 31.30 & 0.70 & 0.04 & 0.00 & 0.41 & 0.10 & 0.80 & 0.04 & 7.35 & 98.57 \\
\hline$R B L$ & 72.06 & 0.44 & 11.61 & 3.13 & 0.7 & 0.00 & 0.57 & 4.50 & 4.34 & 0.01 & & 99.55 \\
\hline
\end{tabular}

Where: $R D M, R B D, R B B, R B L$ are: parent rock.

The main tendency is the loss of alkaline and alkaline earths, but some profiles show relatively high concentration of potassium throughout their profiles, for example: Bana $(0.80-6.40 \%)$ and Batié $(0.70-6.75 \%)$. The silica contents vary from $38.43-49.83 \%$ in the Dschang profile, 66.50 to $70.21 \%$ in the Batié profile, $32.67-69.43 \%$ in the Bangoua profile and $51.50-64.10 \%$ in the Bana profile. The silica contents are near uniformly distributed within 
the Batié, Bangoua and Bana profiles. The alumina contents vary from 21.22-32.83\%, 16.08-20.03\%, 16.71-27.41\% and 23.60-31.30\%, respectively in the Dschang, Batié, Bana and Bangoua profiles. In the Dschang, Batié and Bangoua profiles aluminum contents decrease with depth. The amount of percent water through loss on ignition (LOI) is considerable. It is more than 3\% in all profiles: (12.55-25.14\%) at Dschang; $(3.75-7.68 \%)$ at Batié; (5.77-11.67\%) at Bangoua; and (3.15-9.45\%) at Bana. The iron content varies from 2.45 to $10.86 \%, 1.10-4.90 \%$, $1.52-20.27 \%$ and $0.60-5.80 \%$, respectively in Dschang, Batié, Bangoua, and Bana profiles. The content of titanium $\left(\mathrm{TiO}_{2}\right)$ is high in some profiles such as in Dschang (1.11-2.13\%) and Bangoua (0.19-7.59) soils. The Bangoua profile surface horizon has $7.59 \% \mathrm{TiO}_{2}$.

The variation of chemical composition with depth (Figure 5) of some elements such as $\mathrm{SiO}_{2}, \mathrm{Al}_{2} \mathrm{O}_{3}$, and $\mathrm{Fe}_{2} \mathrm{O}_{3}$ indicates their different evolution.
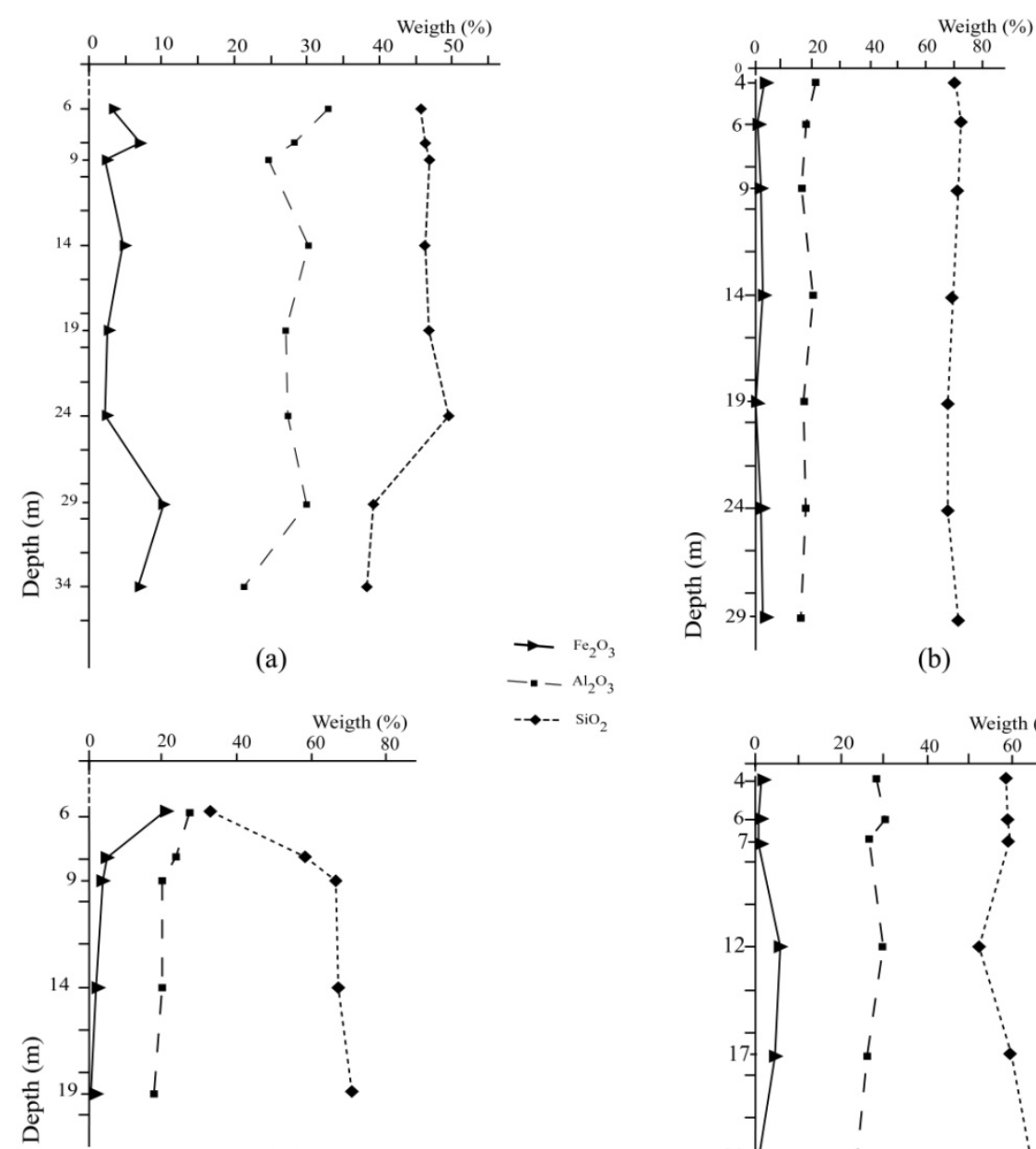

(c)

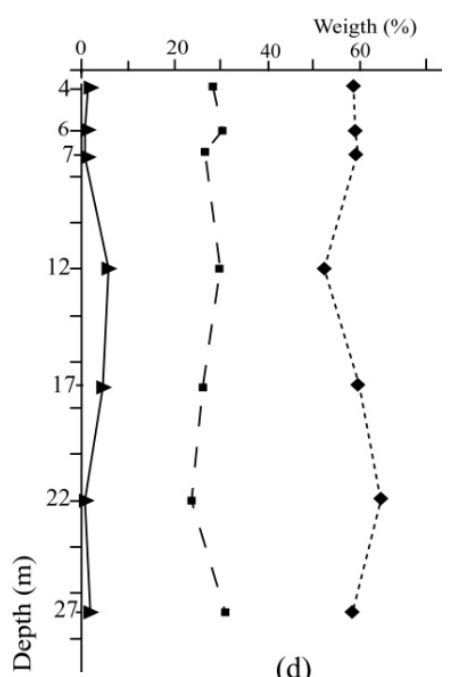

Figure 5. Depth functions of silica, alumina and iron of weathered granites of each profile: a) Dschang, b) Batié, c) Bangoua, and d) Bana

No definite depth functions are indicated for all elements. $\mathrm{SiO}_{2}$ shows a high loss at the surface and tends to remain constant from the $9 \mathrm{~m}$ depth downwards (Figure 5c); it shows near constant depth functions for Figure $5 \mathrm{~b}$ and $5 \mathrm{~d}$, with a slight decrease in the subsurface of $5 \mathrm{a} . \mathrm{Fe}_{2} \mathrm{O}_{3}$ and $\mathrm{Al}_{2} \mathrm{O}_{3}$ have similar depth functions and tend to remain constant with depth except within the lower part of the profile (Figure 5a) where depth trends are erratic. The $\mathrm{SiO}_{2} / \mathrm{Al}_{2} \mathrm{O}_{3}$ ratio varies from 1 to 2 at Dschang, Bangoua and Bana, and from 3 to 4 at Batié. 
The Chemical Index of Alteration (CIA) proposed by Nesbitt and Young (1982) to evaluate the intensity of weathering is used in this study. The values of parent rocks and saprolitic materials are directly represented on the A-CN-K triangle (Figure 6a). Most samples plot high on the diagram, reflecting preponderance of aluminium clay minerals. The slope of predicted and observed trends lie parallel to the A-Kf boundary, as with increasing weathering, potassium feldspar has been destroyed and $\mathrm{K}$ is selected from the residues in preference to $\mathrm{Al}$ and thus trend toward the A apex. The A-CNK-FM diagram introduced by Nesbitt and Young (1989) to illustrate the relationship between leucocratic and melanocratic constituents in a weathering profile is also used (Figure 6b).

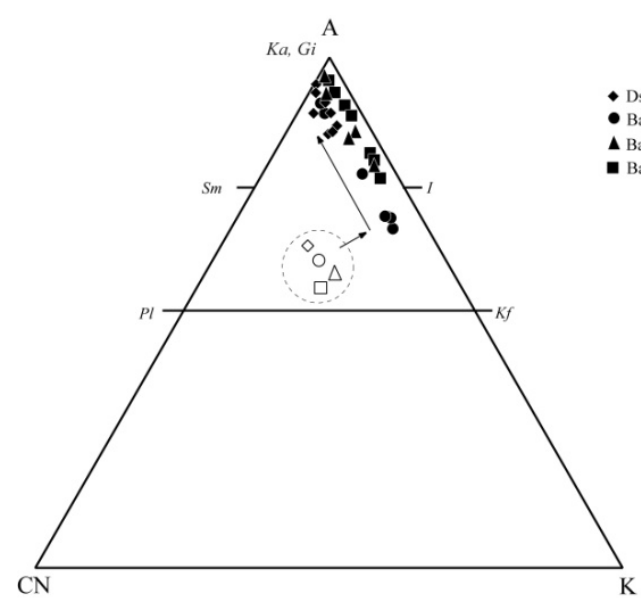

(a)

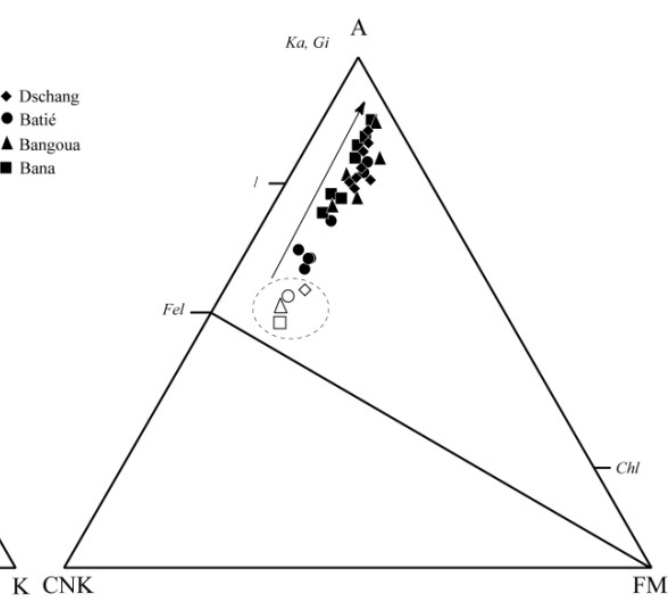

(b)

Figure 6. Evaluation of weathering trends and weathering intensity: (a). A-CN-K diagram illustrating the weathering trend of saprolitic materials, $\mathrm{A}-\mathrm{Al}_{2} \mathrm{O}_{3} ; \mathrm{K}-\mathrm{K}_{2} \mathrm{O} ; \mathrm{CN}-\mathrm{CaO}^{*}+\mathrm{Na}_{2} \mathrm{O} ; \mathrm{Pl}-$ plagioclase;

Kf-K-feldspar; Sm—smectite; I—illite; Ka—kaolinite; Gi—gibbsite (Nesbitt and Young, 1984; 1989). (b). A-CNK-FM diagram illustrating the weathering trend, $\mathrm{A}-\mathrm{Al}_{2} \mathrm{O}_{3} ; \mathrm{CNK}-\mathrm{CaO} *+\mathrm{Na}_{2} \mathrm{O}+\mathrm{K}_{2} \mathrm{O} ; \mathrm{FM}-\mathrm{FeO}$ (total $\mathrm{FeO})+\mathrm{MgO}$; Fel—feldspar; Chl—chlorite; I—illite; Ka—kaolinite; and Gi—gibbsite (Nesbitt \& Young, 1989; Nesbitt et al., 1996). $\mathrm{CaO}^{*}$ is the amount of $\mathrm{CaO}$ incorporated in the silicate fraction of the rock. Solid arrows show the general trends as weathering increases. Dashed circles indicate source composition

As seen in these diagrams, analyzed saprolitic samples from weathering profiles on granites plot above the feldspar join, indicating that feldspars are the dominant Al-bearing minerals in these rocks. The general trend evolves towards the A apex, reflecting the preponderance of aluminium containing clay minerals within them. Most samples lie along the A-K joint, reflecting enrichment in $\mathrm{K}$, possibly due to secondary illitization as reported by Fedo et al. (1995). The XRD patterns confirm the presence of illite which remains in all profiles in spite of high weathering. The geochemical characteristics of weathered materials show a considerable amount of $\mathrm{K}_{2} \mathrm{O}$.

In the A-CNK-FM diagram (Figure 6b), saprolitic materials are displaced toward the A-CNK edge and the A apex, reflecting again the dominance of aluminum clays. Figure 7 illustrates the weathering intensity (CIA values) of rock samples collected, and plotted on a summary diagram.

As seen in this diagram, the parent rock yields values between 55 and 60 whereas those from weathered samples vary between 64-96\%: (85-94\%) of weathered samples from Dschang; (65-90\%) from Batié; (79-96\%) from Bangoua; and (76-96\%) from Bana. Some parent rocks are plotted above the Pl-Kf join between rocks discoloured by weathering. The parent rock of Dschang is very highly weathered. This study indicates that, all these parent rocks are not fresh, but are undergoing initial weathering. This figure shows the same tendency as observed in the A-CN-K diagram. All samples lie along the A-K join. The CIA values obtained in this study vary from $68 \%$ to $95 \%$. They increase with increasing weathering. The $\mathrm{pH}$ of the samples studied ranged from 3 to 4.5 indicating the very acid nature of the environment. 


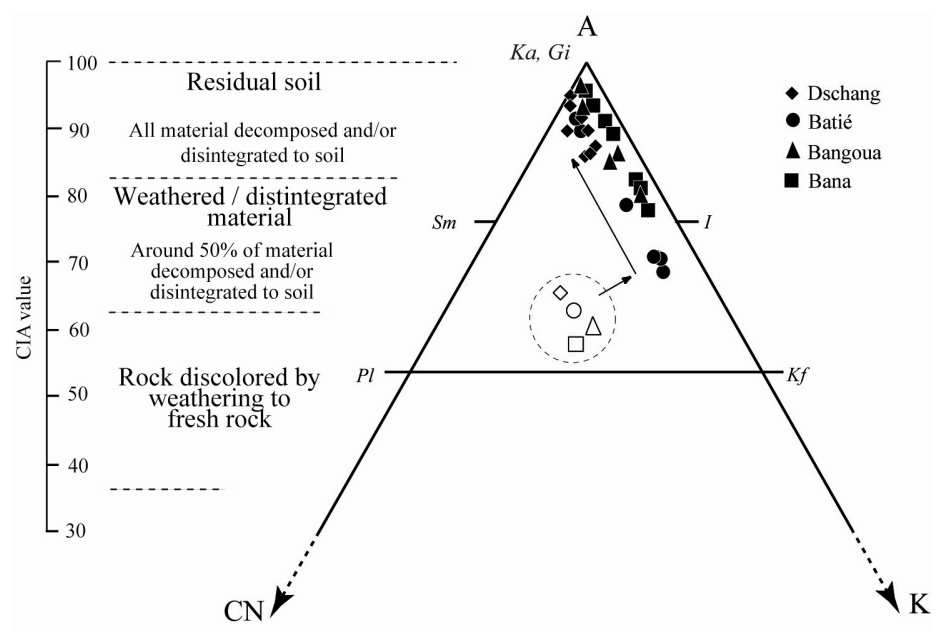

Figure 7. A-CN-K diagram illustrating weathering intensity (CIA values) of samples collected from the west region of Cameroon. The CIA scale is divided into the simplified typical weathering profile described by the Geological Society of London (Lambe, 1996)

\subsection{Scanning Electron Microscope Observation}

As a whole, the quartz and K-feldspar crystals examined show many etch pits on the overgrown surfaces (Figures 8: a, b, c, d; Figures 9: a, b, c, d). These etch pits are similar to those observed in nature or experimentally on quartz grains and feldspar grain surfaces by previous investigations (Crouk, 1968; Cleary \& Connoly, 1972; Al-Saleh \& Khalaf, 1982; Kitagawa et al., 1994; Dove, 1995; Hochella Jr \& Banfield, 1995; White, 1995; Wilson, 1995).
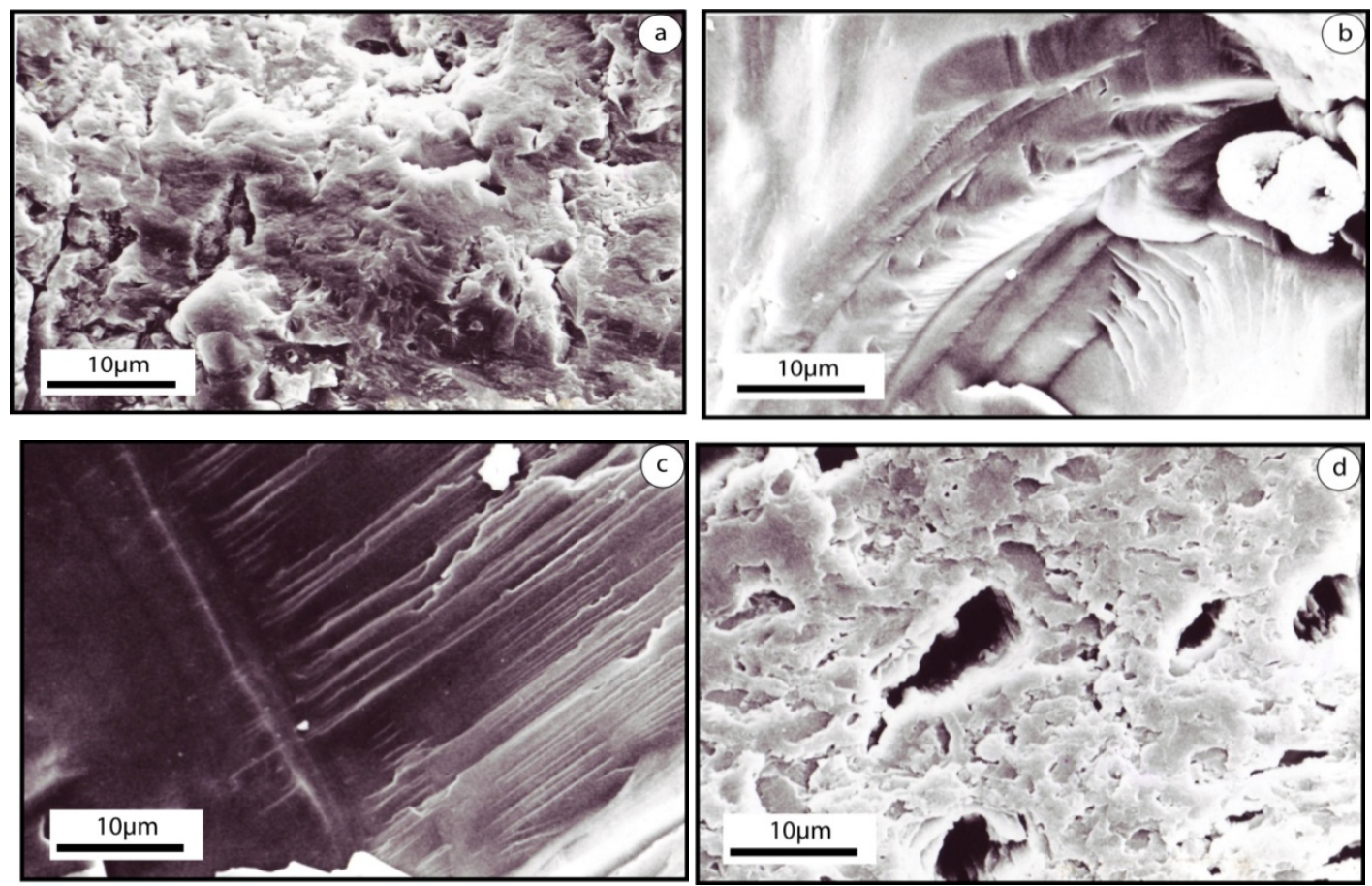

Figure 8. Scanning electron micrographs of specimens collected from weathered granite showing: a) etch pits on a quartz grain of Dschang (DM5); b) small striations and gooves on a quartz of Batié (BD7); c) big striations associated with stepped cleavage planes on a quartz of Bangoua (BB3); and d) irregular surface features and deep grooves on a quartz of Bana (BL3) 

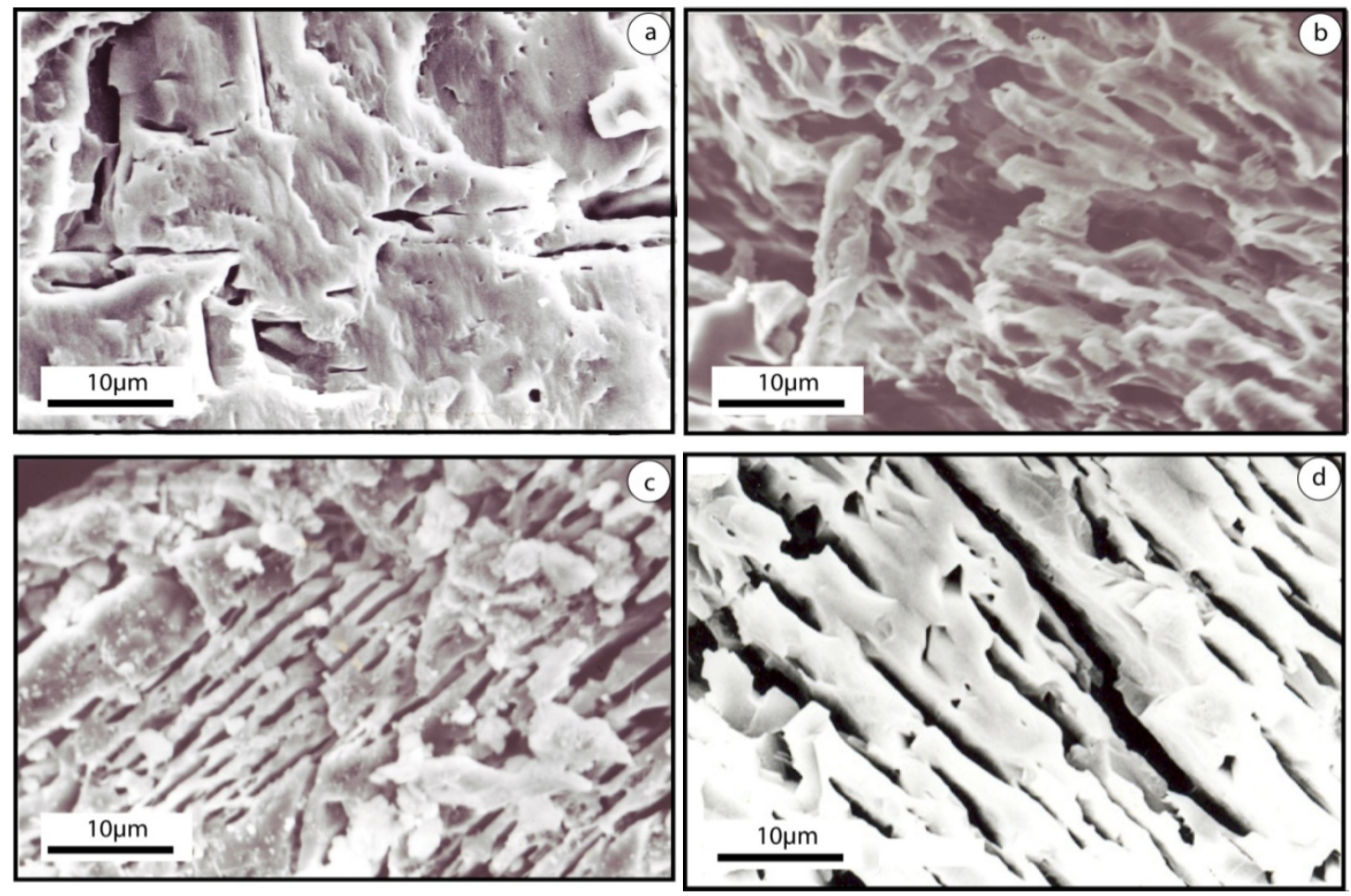

Figure 9. Scanning electron micrographs of specimens collected from weathered K-feldspar showing: a) conical hollows on a K-feldspar of Dschang (DM5); b) oriented coalescent pits developed on a K-feldspar of Batié (BD7;

c) oriented coalescent pits on a K-feldspar of Bangoua (BB3); d) coalescent pits with conical hollows on a K-feldspar of Bana (BL3)

Meticulous observations of saprolites developed in situ on the weathered granitic rocks of Dschang, Batié, Bangoua and Bana reveal a gradual change in morphology of grains, from angular pitted grain surfaces to rounded surfaces. In Figure 8a, irregular pits and grooves interrupt the plane surface. The groove is very pronounced at the lower part of the photograph whereas the upper part shows triangular pits of varying sizes. The striations and curved sutures are developed in some quartz grains collected from Batié (Figure 8b). Samples collected from Bangoua (Figure 8c) show that the right part of the grain appears to have flaked out, leaving flat and irregular surfaces. Those collected from Bana (Figure 8d) show rough surfaces with deep holes of varying sizes. These etch pits show triangular, circular and hexagonal shaped patterns. Although etch pits have various size distribution, most pits are smaller than $5 \mu \mathrm{m}$ in size. The most common etching patterns include triangular etching pits, irregular solution pits, deep grooves and other less pronounced textures of chemical dissolution. In Figures 8a and 8b, chemical weathering appears to start from the zone of weakness and spreads outwards.

$\mathrm{K}$-feldspar grains from weathered granite collected from the same localities exhibit crystallographically controlled etched pits showing uniformity of pitting. These are microperthite coalesced features which now form channels. The c-axis is in the direction of the etch pit elongation (Figures 9a, 9b, 9c and 9d) on samples from Dschang, Batié, Bangoua and Bana, respectively. Some K-feldspar grains Dschang (Figure 9a) show conical hollows. In most samples, casts of horizontal channels connect pits intersecting with the original surface. The K-feldspar etch pits are in general rectangular. Many samples exhibit faces with a very high density of elongated etch pits, many of which have coalesced to form deep eroded channels, several microns in length. All these types and shapes of etch pits confirm the chemical action and the high degree of weathering these quartz and K-feldspar grains have been subjected to.

\section{Discussion}

Factors common to the tropics such as high rainfall and high temperature, which are proper to the area of study, do play a major role in the development of the chemical features recorded on the quartz and K-feldspar grains. However, their origin and evolution remain unknown. Following the geological setting of the area, the occurrence in the profiles of many microfractures, cracks and micro fissures on sand grains as well as in the saprolite, which 
are moreover filled by clay minerals is indicates that silica concentrations in pore solutions play an important role and can be considered as a key factor for etch pit features.

Many field and laboratory studies have examined the decomposition of quartz-bearing and K-feldspar source rocks and the resulting detritus, attempting to correlate grain sizes and textures with weathering and paleoclimate histories (Helland et al., 1997; Wei-Min et al., 1998). As an example, Moss et al. (1981) observed experimentally that grain fragmentation was attributed to the combined physical and chemical effects on the degradation of minerals. In their work on quartz formation in a humid tropical environment, Pye (1983) and Pye and Marzzuli (1994) also observed that quartz grain fragmentation occurs through silica solution penetration along micro fractures and dislocation defects. These findings confirm the hypotheses that weathering processes are primary mechanisms in the formation of silt-sized particles. However, Asumadu et al. (1988) suggested that fragmentation processes on quartz described above are so extensive to validate the use of quartz as a stable index mineral in soil pedogenesis studies. Morey et al. (1962) and Dove (1995) also noted that quartz dissolution must continue indefinitely into silica under saturated solutions. Crouk (1968), Cleary and Connoly (1972) and Dove (1995) proposed that weathering intensity, climate and soil development can be qualitatively measured by the degree and amount of roundness and the embayment of grain surfaces. Field observations show that inorganic solutes act as catalyzing agents in the surface corrosion of quartz mineral grains in soil environments; this can be observed in our region of study where rainfall is very high.

Brantley et al. (1986b) studying the dissolution at dislocation etch pits in quartz proposed that pit development is governed by the aqueous silica concentration such that pits cannot nucleate above a critical saturation state. They also suggested that the shallow flat-bottomed pits correspond to a surface defect while the pyramidal pits are caused by line defects. These features are observed on quartz grains from the samples studied (Figure 8a). Hicks (1985) also described similar features in hydrothermally etched natural quartz. The shape and size of etched pits in quartz have been found to be crystallographically controlled (Wegner \& Christie, 1983). The shape of etch pits is controlled by the relative dissolution rate in different crystallographic directions, just as final crystal shapes are determined by relative rate of growth in different directions. These features are also observed on quartz grains (Figures 8a, b, c and d) in this study. Hydrothermally etched pits on the rhombohedra faces of quartz grains are characteristically pyramidal, with triangular bases uniformly oriented with respect to the crystal. Al-Saleh and Khalaf (1982) showed that signs of chemical etching are manifested on the quartz grains by the presence of deep grooves (Figure 8d), which are mostly due to the solution of silica penetration along micro fractures near an alkaline surface.

The surface features of quartz and K-feldspar grains from the different localities in the West Region of Cameroon reveal the occurrence of triangular pits and deep grooves as shown in Figures 8 and 9. Chemical features generated by etching are mostly developed in the grains. The occurrence of etched pits is attributed mainly to chemical weathering process in spite of the slight mechanical weathering. In these environments quartz grains are affected by pore water for relatively long periods of time.

Investigations of etched pit densities on naturally weathered surfaces suggest that dissolution from etched pits increase with long exposure time to weathering conditions (Anbeek et al., 1994). Bennett (1991) asserted that, the organic acids appear to increase dissolution rates. The observation of pitting which changes as a function of depth suggests that the existence of etched pits is controlled by some depth-related factors. As fluids pass through the profile, silica dissolved from the soil grains increase the silica concentration towards saturation, as obtained experimentally by Brantley et al. (1986). The surface morphology of the weathered sand grains which show differing patterns of etching, may result from eluviation processes. Dissolution at these depths occur primarily at grain contacts (corners and edges) producing round grains. Some rounded grains of quartz were observed in the lower part of profiles. This may have resulted from downward transport of surface materials along fractures and micro cracks induced by shrinkage during weathering or leaching, or they may have formed in-situ from silica-rich solutions. These observations, are supported by the presence of rounded quartz grains at the base of the profiles, which further indicates that quartz dissolution is continuing at all depths as reported by Brantley et al. (1986).

Apparently, the surface horizons are subject to more severe weathering in agreement with previous works (Wouatong et al., 1996, 2005). Based on the thickness of the weathering mantle, the conditions of good drainage and leaching also affected the lower part of profiles. This is confirmed first, by the presence of gibbsite formed probably through the transformation of kaolinite into gibbsite (allitisation process) associated with good drainage and high leaching intensity resulting in the loss of silica into solution and secondly, by the amount and shape of etched pits observed on quartz grain surfaces. In some profiles, this observation is confirmed by the presence of gibbsite in the lower part (Figures $4 \mathrm{a}, 4 \mathrm{~b}$ and $4 \mathrm{c}$ ). Following the XRD data and the geochemical composition of the saprolitic materials, the geochemical processes are dissolution and hydrolysis through monosiallitisation and 
allitisation. The degree of weathering is one of the most significant factors controlling the type and abundance of clay minerals as pointed out by Duzgoren-Aydin et al. (2002) and Aristizabal et al. (2005). Tropical weathering of granites in the West Region is characterized by loss of $\mathrm{SiO}_{2}, \mathrm{CaO}, \mathrm{Na}_{2} \mathrm{O}$ and $\mathrm{MgO}$ and an increase in $\mathrm{Al}_{2} \mathrm{O}_{3}$ and $\mathrm{K}_{2} \mathrm{O}$. Mineralogically, these chemical changes reflect the formation of secondary clay minerals, predominantly kaolinite and sesquioxydes. The $\mathrm{SiO}_{2} / \mathrm{Al}_{2} \mathrm{O}_{3}$ ratios vary between 1 and 4 depending on the profile: (less than 2 in Dschang; (3-4 in Batié); (1-4 in Bangoua); and (1-2 in Bana). This data suggests that bisiallitisation also took place but was metastable and consisted only of the transformation of illite/smectite to $1 / 1$ minerals. The chemical composition of the bulk materials gives a large amount of water as loss on ignition (LOI) showing that the water table level is high and the whole profile remains moist during the year. The triangular etched pits of our study are very similar to those observed in the single crystal experiments of Brantley et al. (1986) and Hicks (1985). According to these experiments, sand dissolution took place at very high and very low temperatures. Brantley et al. (1986) concluded that the concentration of silica could control pitting from experiments they carried out at high temperatures. A more thorough investigation of chemical etching as a function of soil depth and/or increasing weathering and fluid chemistry is necessary in order to provide further information and insights into fluid history in the weathering environment.

\section{Conclusion}

Mineralogical composition obtained from saprolitic materials developed on granites of the West Region of Cameroon reveals the occurrence of illite, kaolinite and the appearance of gibbsite in the upper and lower parts of profiles. The geochemical composition of the weathered mantle reveals the loss of $\mathrm{CaO}, \mathrm{Na}_{2} \mathrm{O}$ and $\mathrm{MgO}$, small amounts of $\mathrm{SiO}_{2}$ and an increase of $\mathrm{Al}_{2} \mathrm{O}_{3}$ and $\mathrm{K}_{2} \mathrm{O}$. The chemical index of alteration (CIA) is very high and reveals the highest degree of chemical weathering. Chemical features widely recorded are attributed to etching developed in most of the samples. These features are common in residual minerals (quartz and K-feldspar grains) exposed to different levels and conditions of weathering, good drainage and high leaching. The different forms of etched pits recorded and their evolution with increasing weathering are related to the silica concentrations in pore solution.

The concentration of quartz throughout all the profile as indicated by XRD data confirms the high weathering intensity indicated by the dissolution pitting on quartz grains in the Scanning Electron Micrographs. Equally, the presence of gibbsite both in upper surface and sub-surface horizons confirms high weathering intensity throughout the profiles to depths exceeding $30 \mathrm{~m}$. The results indicate that the pathways for mineral weathering follow the trend granite (contain the minerals: quartz / K-feldspar / mica) $\rightarrow$ illite $\rightarrow$ kaolinite $\rightarrow$ gibbsite / goethite. In view of the high concentration of weathered minerals throughout the profile more studies need to be carried out to evaluate the quantity and quality of these materials for application in the ceramic industry.

\section{Acknowledgments}

The authors thank Professor Ryuji Kitagawa of Hiroshima University, Faculty of Science, Graduate School of Science for XRD, chemical analysis and SEM and their comments and valuable discussions of analytical results. We appreciate the comments on the earlier version of the manuscript by Professor Tchoua.

\section{References}

Al-Sahel, S., \& Khalaf, F. I. (1982). Surface texture of quartz grains from various recent sedimentary environment in Kuwait. Journal of Sedimentology Petrology, 52(1), 215-225.

Anbeek, C., Van Breemen, N., Meijer, E .L., \& Van der Plas, L. (1994). The dissolution of naturally weathered feldspar and Quartz. Geochim Cosmochim Acta, 58, 4601-4613. http://dx.doi.org/10.1016/0016-7037(94)90194-5

Aristizabal, E., Barry, R., \& Shuichiro, Y. (2005). Tropical chemical weathering of hillslope deposits and bedrock source in the Aburra Valley, northern Colombia Andes. Engineering Geology, 81, 389-406. http://dx.doi.org/10.1016/j.enggeo.2005.08.001

Asumadu, K., Gilles, R. J., Armitage, T. M., \& Churchward, H. M. (1988). The effects of chemical weathering on morphology and strength of quartz grains and example S.W. Australia Journal Soils Science, 39, 375-383. http://dx.doi.org/10.1111/j.1365-2389.1988.tb01223.x

Bener, R. A. (1981). Kinetics of weathering and diagenesis. In A. C. Lagassa, \& T. J. Kirkpatrick (eds), kinetics of geochemical processes. Reviews in Mineralogy, 8, 111-134.

Bennett, P. C. (1981). Quartz dissolution in inorganic-rich aqueous system. Geochim Cosmochim Acta, 55, 1781-1797. http://dx.doi.org/10.1016/0016-7037(91)90023-X

Berner, R. A., \& Holdrem, G. R. (1979). Mechanism of feldspar weathering II. Observation of feldspar from soil. Geochim Cosmochim Acta, 43, 1173-1186. 
Berner, R. A., Sjoberg, E. L., Velbel, M. A., \& Krom, M. D. (1980). Dissolution of pyroxenes and amphiboles during weathering. Science, 1205-1206.

Brantley, S. L., Gane, S. R., Gerar, D. A., Hellman, R., \& Stallard, R. (1986). Dissolution at dislocation etch pits in quartz. Geochim Cosmochim Acta, 50, 2349-2361. http://dx.doi.org/10.1016/0016-7037(86)90087-6

Brindley, G. W., \& Brown, G. (1980). Crystal structures of clay minerals and their X-ray identification. London: Mineralogical Society.

Cleary, W. J., \& Conolly, J. R. (1972). Embayed quartz grains in soils and their signification. Journal of Sedimentology Petrology, 42, 899-904.

Crook, K. A. W. (1968). Weathering and roundness of quartz sand grains. Sedimentology, 11, 171-182. http://dx.doi.org/10.1111/j.1365-3091.1968.tb00851.x

Deepthy, R., \& Balakrishnan, S. (2005). Climatic controle on clay mineral formation: Evidence from weathering profiles developed on either side of the Western Ghats. Journal of Earth System Science, 114(5), 545-556.

Dove, P. M. (1995). Kinetic and thermodynamic controls on silica reactivity in weathering environments. Reviews in Mineralogy, 31, 235-290.

Drees, L. R., Wilding, L. P., Smeck, N. E., \& Senkayi, A. L. (1989). Silica in soils: quartz and disordered silica polymorphs. Reviews in Mineralogy, 31, 237-290.

Duane, M., M., Robert, C., \& Reynold, J. R. (1989). X-Ray diffraction and the identification and analysis of clay minerals. New York: Oxford.

Duzgoren-Aydin, N. S., Aydin, A., \& Malpas, J. (2002). Distribution of clay minerals along a weathered pyroclastic profile, Hong Kong. Catena, 50, 17-41. http://dx.doi.org/10.1016/S0341-8162(02)00066-8

Fedo, C. M., Nesbitt, H. W., \& Young, G. M. (1995). Unravelling the effects of potassium metasomatism in sedimentary rocks and paleosols, with implications for paleoweathering conditions and provenance. Geology, 23, 921-924. http://dx.doi.org/10.1130/0091-7613(1995)023<0921:UTEOPM>2.3.CO;2

Heaney, P. J. (1994). Structure and chemistry of the low-pressure silica polymorphs. Reviews in Mineralogy, 31, 237-290.

Helgson, H. C., Murphy, W. M., \& Aagaard, P. (1984). Thermodynamic and kinetic constraints on reaction rates among minerals and aqueous solutions. II. Rate constants effective surface area, and the hydrolysis of feldspar. Geochim Cosmochim Acta, 48, 2405-2432. http://dx.doi.org/10.1016/0016-7037(84)90294-1

Helland, P. E., Huang, P. H., \& Diffendal, R. F. (1997). SEM analysis of quartz sand grain surface textures indicates alluvial/colluvial origin of quaternary "glacial" boulder clays at Huangshan (Yellow Mountain). Quaternary Research, 48, 177-186. http://dx.doi.org/10.1006/qres.1997.1916

Hicks, B. D. (1985). Quartz dissolution features. An experimental and petrofabric study. Goechim Cosmochim Acta, 50, 2349-2361.

Hochella, Jr. M. F., \& Banfiel, J. F. (1995). Chemical weathering of silicates in nature: A microscopic perspective with theoretical considerations. Reviews in mineralogy, 31, 353-406.

Kamgang, K. B. V., Onana, V. L., Ndome, E. E. P., Parisot, J. C., \& Ekodeck, G. E. (2009). Behaviour of REE and mass balance calculations in a lateritic profile over chlorite schists in South Cameroun. Chemie der Erde Geochemistr, 69, 61-73. http://dx.doi.org/10.1016/j.chemer.2008.08.003

Kitagawa, R., Koster H. M., Yeon, H. J., Zaikov, V. V., \& Udachim, V. N. (1994). Scanning electron microscope examination of quartz surface textures from kaolinized granitic rocks. Journal of Science of Hiroshima University, Series C. 10, 159-172.

Knauth, L. P. (1994). Petrogensis of chert. In P. J. Heaney, C. T. Prewitt, \& G. V. Gibbs (eds.), Silica: Physical behaviour, Geochemistry, and Materials Applications. Reviews in Mineralogy, 29, 233-258.

Krinsley, D., \& Cavallero, L. (1970). Scanning electron microscopic examination of periglacial eolian sands from long Island, New York. Journal of Sedimentology Petrology, 40, 1345-1350.

Kuepouo, G. (2004). Geology, petrology and geochemistry of the Tertiary Bana volcano-plutonic complex, west Cameroon, Central Africa. PhD Thesis. Kobe University.

Kwekam, M. (2005). Genèse et évolution des granitö̈des calco-alcalins au cours de la tectonique panafricaine : le cas des massifs syn à tardi-tectoniques de l'ouest-Cameroun (régions de Dschang et de Kékem). Thèse Doctorat d'Etat. Université de Yaoundé I. 
Lambe, P. (1996). Residual soils. Landslide: investigation and mitigation. In: E. Aristizabal et al. Tropical chemical weathering of hillslope deposits and bedrock source in the Aburra Valley, northern Colombia Andes. Engineering Geology, 81, 389-406.

Lasaga, A. (1981). Rate laws of chemical reaction. In kinetics of Geochemical processes. Reviews in Mineralogy, $18,1-110$.

Lasaga, A. (1983). Kinetics of silicate dissolution. $4^{\text {th }}$ International Symposium on Water-Rock Interaction, Extended. Abstract, Misasa, Japan.

Lasaga, A., \& Blum A. E. (1986). Surface chemistry, etch pits and mineral-water reactions. Geochem Cosmochim Acta, 50, 2363-2379. http://dx.doi.org/10.1016/0016-7037(86)90088-8

Lelong, F. (1969). Nature et genèse des produits d'altération de roches cristallines sous climat tropical humide (Guyane Française). Mémoire Science de la Terre, Nancy, 14, 188.

Mackenzie, S. V. (1986). Electron microscopy of chemical solution and mechanical abrasion features on quartz sand grains. Sedimentology Geology, 2, 243-256.

Marzoli, A., Piccirillo, E. M., Renne, P. R., Bellini, G., Lacumin, M., Nyobé, J. B., \& Tongwa, A. F. (2000). The Cameroon volcanic line revisited: petrogenesis of continental basaltic magmas from lithospheric and asthenospheric mantle sources. Journal of Petrology, 41, 87-109. http://dx.doi.org/10.1093/petrology/41.1.87

Milines, A. R., Wright, M. J., \& Thiry, M. (1991). Silica accumulations in saprolites and soils in South Australia. In P.M. Dove, Reviews in Mineralogy, 31, 237-290.

Millot, G. (1970). Geology of clays, weathering, sedimentology, geochemistry. Springer-Verlag, 429.

Millot, G. (1971). Géochimie des altérations. Bulletin Service. Carte Géol. Alsace-Loraine, 24, 181-217.

Moreau, C., Regnoult, J. M., Deruelle, B., \& Robineau, B. (1987). A new tectonic model for the Cameroon line, Central Africa. Tectonophysics, 13, 317-334. http://dx.doi.org/10.1016/0040-1951(87)90206-X

Morey, G. W., Fournier, R. O., \& Rowe, J. J. (1962). The solubility of quartz in water in the tem erature interval from 25 to $300^{\circ} \mathrm{C}$. Geochem Cosmochim Acta, 22, 1029-1043.

Moss, A. G., Green, P., \& Hulka, J. (1981). Static breakage of granitic detritus by ice and water in comparison with $\begin{array}{lllll}\text { breakage be flowing } & \text { water. }\end{array}$ http://dx.doi.org/10.1111/j.1365-3091.1981.tb01679.x

Nahon, D. (1991). Introduction to the petrology of soils and chemical weathering. NewYork: John Wiley \& Sons.

Nahon, D., Colin, F., \& Tardy, Y. (1982). Formation and distribution of Mg, Fe, Mn-smectites in the first stages of the lateritic weathering of fosterite and tephroite. Clay Minerals, 17, 1-9. http://dx.doi.org/10.1180/claymin.1982.017.3.06

Nahon, D., Jano, H., Parron, C., \& Millot, G. (1979). Epigénie du quartz et de la kaolinite dans les accumulations ferrugineuses superficielles. La signification des goethites et hématites alumineuses. Sciences Géologiques Bulletin, 32(4), 165-180.

Nana, J. M. (1988). Le complexe volcano-plutonique de Bana (Ouest-Cameroun): Géologie et pétrologie. Thèse Université, Paris- Sud (Centre d'Orsay).

Ndjigui, P. D., Bilong, P., Bitom, D., \& Dia, A. (2008). Mobilization and redistribution of major and trace elements in two weathering profiles developed on serpentinites in the Lomié ultramafic complex, South-East Cameroun. Journal of African Earth Sciences, 50, 305-328.

Nesbitt, H. W., \& Young, G. M. (1982). Early Proterozoic climates and plate motions inferred from major element chemistry of lutites. Nature, 279, 715-717. http://dx.doi.org/10.1038/299715a0

Nesbitt, H. W., \& Young, G. M. (1989). Formation and diagenesis of weathering profiles. Journal of Geology, 97, 129-147. http://dx.doi.org/10.1086/629290

Nesbitt, H. W., Young, G. M., McLennan, S. M., \& Keays, R. R. (1996). Effects of chemical weathering and sorting on the petrogenesis of siliciclastic sediments, with implication for provenance studies. Journal of Geology, 104, 525-542. http://dx.doi.org/10.1086/629850

Ngako, V., Jegouz, P., \& Nzenti, J. P. (1991). Le cisaillement centre camerounais. Rôle structural et géodynamique dans l'orogenèse panafricaine. Compte Rendus Académie des Sciences (Paris), 313, 357-463. 
Nguetnkam J. P., Kamga, R., Villiéras, F., Ekodeck, G. E., \& Yvon, J. (2008). Altération différentielle du granite en zone tropicale. Exemple de deux séquences étudiées au Cameroun (Afrique centrale). Compte Rendu Géoscience, 340, 451-461. http://dx.doi.org/10.1016/j.crte.2008.02.002

Njanko, T., Nedelec, A., \& Affaton, P. (2006). Synkinematic high-K calc-alkaline plutons associated with the Pan-African Central Cameroon shear zone (W-Tibati area): petrology and geodynamic significance. Journal of African Earth Science, 44, 494-510. http://dx.doi.org/10.1016/j.jafrearsci.2005.11.016

Pedro, G. (1964). La genèse des hydroxydes d'aluminium par altération expérimentale des roches cristallines et le problème des latérites. International Geology Congres, 22(14), 1-13.

Pedro, G. (1968). Distribution des principaux types d'altération chimique à la surface du globe. Présentation d'une esquisse géographique. Revue Géographique Physique Géologie Dynamique Paris, 10, 457-470.

Pye, K. (1983). Formation of quartz silt during humid tropical weathering of dune sands. Sedimentology Geology, 34, 267-282. http://dx.doi.org/10.1016/0037-0738(83)90050-7

Pye, K., \& Marzzuli, J. (1994). Effects of tropical weathering on quartz grains shape. An example from Northeasten Australia. Journal of Sedimentology Petrology, 64, 500-507.

Reynolds, S., \& Gorsline, D. S. (1991). Clay micro-fabric of deep sea, detrital mud (stone)s, California continental borderland. Journal of Sedimentology Petrology, 62, 41-53.

Robinson. Jr. G. D. (1980). Possible quartz synthesis during weathering of quartz-free mafic rock, jasper country, Georgia. Journal of Sedimentology Petrology, 50, 193-203.

Stanley, V. M. (1968). Electron microscopy of chemical solution and mechanical abrasion features on quartz sand grains. Sedimentology Geology, 2, 243-256. http://dx.doi.org/10.1016/0037-0738(68)90002-X

Tagne-Kamga, G. (2003). Petrogenesis of the Neoproterozoic ngondo plutonic complex (Ca-Maroon, West central Africa): a case of late collisional ferro-potassic magnetism. Journal of African Earth Sciences, 36, 149-171.

Talla, V. (1995). Le massif granitique panafricain de Batié (Ouest-Cameroun) : pétrologie-structurale-géochimie. Thèse Doctorat $3^{\mathrm{ème}}$ cycle, Université de Yaoundé I.

Tardy, Y. (1993). Pétrologie des latérites et des sols tropicaux. Masson.

Tchoua, F. M. (1974). Contribution à l'étude géologique et pétrographique de quelques volcans de la Ligne du Cameroun. (Monts Manengouba et Bamboutos). Thèse Doctorat d'Etat. Université Clermont Ferrand, France.

Wandji, P. (1995). Le volcanism recent de la plaine du Noun (Ouest-Cameroun). Volcanologie, Pétrologie, Géochimie et Pouzzolanicité. Thèse Doc. Etat, Uni. Yaoundé I. Yaoundé, Cameroun.

Wegner, M. W., \& Christie, J. M. (1983). Chemical etching of deformation substructure in quartz. Physic and Chemical Minerals, 9, 67-78. http://dx.doi.org/10.1007/BF00308150

Wei-Min, W., Hsueh-Wen,Y., Pei-Yuan, C., \& Ming-Kuang, W. (1998). Kaolin mineralogy of clays in paleosol profiles on the Late-Miocene sediments in Penghu Islands (Pescadores), Taiwan. Clays and Clay Minerals, 46(1), 1-9. http://dx.doi.org/10.1346/CCMN.1998.0460101

White, A. F. (1995). Chemical weathering rates of silicate minerals in soils. Reviews in Mineralogy, 31. Chemical weathering rates of silicate minerals. Mineralogical Society of America, 409-461.

Wilson, P. (1995). A scanning electron microscope examination of quartz grain surface textures from the weathered millstone grit (carboniferous) of the southern pennins, England. A preliminary report, 319-328.

Wintsch, R. P., \& Dunning, J. (1985). The effect of dislocation density on the aqueous solubity of quartz and some geology implications; A Theoretical approach. Journal of Geophysic Research, 90, 3649-1657. http://dx.doi.org/10.1029/JB090iB05p03649

Wouatong, A. S. L., Kitagawa, R., Tchoua, M. F., Talla V., \& Njopwouo, D. (2005). Kaolinization of saprolite developed on pana African granite of Batié district, west province of Cameroon. Clay Science Society of Japan, 13, 7-18.

Wouatong, A. S. L., Kitagawa. R., Takeno, S., Tchoua, M. F., \& Njopwouo, D. (1996). Morphological transformation of kaolin minerals from granite saprolite in the western part of Cameroon. Clay Science Society of Japan, 10, 55-99. 